\title{
Shaker A. Zahra: pioneering entrepreneurship scholar
}

\author{
David B. Audretsch
}

Accepted: 12 January 2015/Published online: 19 February 2015

(C) The Author(s) 2015. This article is published with open access at Springerlink.com

\begin{abstract}
This paper provides an analysis of Shaker A. Zahra's contributions to the entrepreneurship literature that, when taken together, provide the basis for his Global Entrepreneurship Award. Professor Zahra has made significant and unique contributions to the literatures on coprorate entrepreneurship, international entrepreneurship and social entrepreneurship.
\end{abstract}

Keywords Corporate entrepreneurship - Knowledge creation $\cdot$ Knowledge conversion $\cdot$ Knowledge integration $\cdot$ Entrepreneurial hubs

JEL Classifications $\quad \mathrm{L} 26 \cdot \mathrm{O} 1 \cdot \mathrm{F} 6$

\section{Introduction}

I first met Zahra (1996). We were, at that time, colleagues at Georgia State University, in Atlanta. He took every opportunity to talk about ideas. Ideas and research. He wanted to know what everyone was up to, what they were working on, and why it should make a difference. To scholars, certainly, but also to the

Prepared for the Occasion of the Presentation of the Global Entrepreneurship Award to Shaker A. Zahra on 3 December 2014, Stockholm.

D. B. Audretsch $(\bowtie)$

Indiana University, Bloomington, IN, USA

e-mail: daudrets@indiana.edu people in the real world. And he was not shy about sharing his own research ideas. I recall my own bewilderment at hearing a litany of research projects, ideas, and papers under various stages of development. He was an idea machine. However, what I found even more striking was the remarkably rich and fertile field of unique, novel, and virtually unexplored topics and themes that he was cultivating. He talked of technological entrepreneurship as a strategic response to transform organizations into leveraging the opportunities afforded by globalization rather than passively becoming another victim of globalization. At that point in time, scholars generally did not take globalization seriously, nor entrepreneurship, for that matter.

Some two decades later, it is gratifying to be able to review and reflect on the monumental impact that Professor Zahra's research and scholarship have had not just on the field of entrepreneurship, but on a considerably broader range of fields spanning a number of important social science disciplines. This paper explains why Professor Zahra's scholarship has been so important in shaping the field of entrepreneurship.

The scholarly research contributed by Professor Zahra has consisted of theoretical, empirical, and institutional contributions. His research has been done in an international context, with applications throughout the world. He has accumulated a superb record of scholarship in the field of entrepreneurship. The research of Professor Zahra has been remarkably diverse and has spanned three main areas and 
literatures within management and strategy-corporate entrepreneurship, international entrepreneurship, and social entrepreneurship. However, it is important to emphasize that Professor Zahra's impact has been considerably broader and extends beyond these research areas, and even beyond the broad fields of management and strategy. His research has been recognized by and had an impact on a broad spectrum of scholars spanning a wide range of fields and disciplines throughout the social sciences.

\section{Corporate entrepreneurship}

The most significant impact of Professor Zahra's scientific output lies in research on corporate entrepreneurship - and that which he addresses in his acceptance speech, see his article in this issue of Small Business Economics Journal. His research has considered three main related themes. The first is entrepreneurship and knowledge creation and exploitation. In particular, he has introduced three key research questions into the literature of corporate entrepreneurship. The first research question is, "What are the types of knowledge being created in the course of the entrepreneurial process?" Prior to Professor Zahra's path-breaking research, knowledge and ideas had been largely treated as being homogenous, with little attention being devoted to how the entrepreneurial process might create different types of knowledge.

The second question extends the first, by asking, "How do different entrepreneurial activities relate to the types of knowledge being created?" Before Professor Zahra's key contribution, little attention had been devoted to linking particular types of entrepreneurial activities to specific types of knowledge. The third question Professor asks, "What are the organizational mechanisms that cultivate and exploit these different types of knowledge?" The answers he proposes in his path-breaking research provided some of the first insights showing how certain organizational mechanisms are more effective in transforming specific types of knowledge into innovative activity than are other types of organizational mechanisms.

In order to address these three questions, Professor Zahra had to clarify and extend the concept of absorptive capacity, which had been introduced by Cohen and Levinthal $(1989,1990)$ and had triggered a rethinking about the innovation process in the social sciences. After Cohen and Levinthal (1989, 1990) introduced this important concept in the late 1980s, the actual application in the field of strategy remained shrouded in ambiguity and fraught with contradictions. An original contribution of Professor Zahra was the introduction of the "knowledge conversion capability" concept as a mechanism for transforming newly created knowledge into viable commercial applications. In his important and path-breaking paper, "Absorptive Capacity: A Review, Reconceptualization, and Extension," written in collaboration with Gerard George, and published in 2002 in the Academy of Management Review, the concept of absorptive capacity is clarified by distinguishing between potential and realized absorptive capacity. Potential capacity comprises knowledge acquisition and assimilation capabilities, and realized capacity focuses on the transformation and exploitation of knowledge. This distinction incorporates absorptive capacity as a dynamic capability that enables a firm to generate and maintain a competitive advantage over time.

The second research theme of Professor Zahra in the area of corporate entrepreneurship focuses on the abilities of entrepreneurial companies to build and use capabilities. While much of the entrepreneurship literature had focused on how new companies develop capabilities, Professor Zahra extended this concept to established companies. His research specifically posed two key questions, "What distinguishes those capabilities developed in new ventures within the context of an established company from those developed by a new company," and "How do the capabilities developed by an established company differ between a new venture and an established venture?" A key contribution of this research has been to delineate the nature of capability building in new ventures and how these capabilities shape organizational outcomes, including internationalization. In collaboration with Harry Sapienza and Per Davidsson, Professor Zahra published "Entrepreneurship and Dynamic Capabilities: A Review, Model and Research Agenda," published in (2006) in the Journal of Management Studies. In particular, this paper is an important and original contribution because the extant literature had focused on the role of dynamic capabilities mainly in established firms. By contrast, Professor Zahra and his coauthors were able to identify the role that such dynamic capabilities play in new firms as they create, discover, and exploit opportunities. 
The third research theme where Professor Zahra has made significant contributions in the area of corporate entrepreneurship is the role of entrepreneurship and learning in the context of global technology-based industries. His paper, "Predictors and Financial Outcomes of Corporate Entrepreneurship: An Exploratory Study," which was published in (1991) in the Journal of Business Venturing triggered a number of subsequent studies by a broad range of scholars trying to understand which factors influence the financial outcomes associated with corporate entrepreneurship. An important contribution of this paper was to provide one of the first and most compelling definitions of corporate entrepreneurship. According to Professor Zahra (1991, p. 261), “Corporate entrepreneurship may be formal or informal activities aimed at creating new businesses in established companies through product and process innovations and market developments. These activities may take place at the corporate, division (business), functional, or project levels, with the unifying objective of improving a company's competitive position and financial performance."

Similarly, his paper, "Governance, Ownership, and Corporate Entrepreneurship: The Moderating Impact of Industry Technological Opportunities," which was published in (1996) in the Academy of Management Journal has had a considerable impact in the literature by examining how corporate entrepreneurship varies between the contexts of high and low technology global industries, sources of variability in the types of corporate entrepreneurship activities, how various corporate entrepreneurship activities influence learning, depth, breadth, and speed, and how the depth, breadth, and speed of learning influence organizational performance in global industries. Most of Professor Zahra's research to address these issues has been based on survey and archival data, along with field interviews conducted with senior managers. An important contribution to the literature by Professor Zahra has been the reformulation of the role of absorptive capacity in organizational learning, along with mapping and measuring the domain of corporate entrepreneurship activities.

\section{International entrepreneurship}

A second major area where Professor Zahra has made a number of key contributions is international entrepreneurship. While the extant literature had considered firms to engage in international activities only after they had evolved sufficiently over their life cycle and attained a certain age, size, and experience threshold, Professor Zahra instead demonstrated that some new ventures and firms are "born global." A particular feature of his research has been to compare those new ventures which are born global from those that internationalize later or sequentially over their life cycle. He has also identified how the performances of new ventures are born global compared to their counterparts who do not internationalize in the earliest stages of their existence.

In his paper, "International Expansion by New Venture Firms: International Diversity, Mode of Market Entry, Technological Learning, and Performance," in collaboration with R. Duane Ireland and Michael A. Hitt, and published in the Academy of Management Journal, Professor Zahra makes three key contributions. The first is an explicit identification of the impact of international diversity and internationalization as a mode of entry on the ability of a new venture to take advantage of technological learning. The second is to examine the impact of knowledge integration on the relationship between internationalization and technological learning. The third is to document the impact of technological learning on the performance of new ventures.

Professor Zahra's paper, “A Capabilities Perspective on the Effects of Early Internationalization on Firm Survival and Growth," co-authored with E. Autio and G. George, and published in the Academy of Management Review, was a pioneering study showing that internationalization strategies have a positive impact on the performance of new firms, measured in terms of survival and growth. While a large number of studies had previously been published identifying various factors and characteristics influencing new firm survival and growth, this was the first paper to explicitly identify the key role that internationalization plays in influencing the growth and survival of new firms.

\section{Social entrepreneurship}

A third major area where Professor Zahra has made significant contributions is in the relatively new field of social entrepreneurship. In "A Typology of Social Entrepreneurs: Motives, Search Processes and Ethical 
Challenges," and published in (2009) in the Journal of Business Venturing, Professor Zahra and his coauthors, E. Gedajlovic, D. Neubaum, and J. Shulman, introduce an original framework for classifying different types of social entrepreneurs. Similarly, in "Globalization of Social Entrepreneurship," in collaboration with H. Rawhouser, N. Bhawe, D. Neubaum, and J. Hayton, and published in (2008) in the Strategic Entrepreneurship Journal, Professor Zahra uses the behavioral theories of pro-social behavior to interpret the motives of social entrepreneurs, as well as to link social entrepreneurship to the internationalization literature.

\section{Other contributions}

Much of Professor Zahra's scholarship within the three major fields outlined above also has made substantial contributions to some other themes in entrepreneurship. While it is beyond the scope of this review of his scholarship to identify and discuss all the linkages in Professor Zahra's research where he connects other themes in entrepreneurship research, it is still important to emphasize several areas where Professor Zahra has made key contributions.

One key area where Professor Zahra has made important contributions is research on family business. His paper, "Entrepreneurship in Family vs. NonFamily Firms: A Resource-Based Analysis of the Effect of Organizational Culture," together with J.C. Hayton and C. Salvato, was published in (2004) in Entrepreneurship Theory and Practice. The paper applies the resource-based theory of the firm to analyze organizational culture in family-owned businesses and contrast it to the organizational culture in non-family-owned businesses. Similarly, his paper on "Entrepreneurial Risk Taking in Family Firms," published in (2005) in Family Business Review, analyzes the role of risk within the context of family-owned business. Professor Zahra's paper, "International Expansion of US Manufacturing Family Businesses: The Effect of Ownership and Involvement," which was published in (2003) in the Journal of Business Venturing, analyzed why and how family businesses in the context of manufacturing in the USA expand to become international.

Another important area where Professor Zahra has had a substantial impact is on corporate performance.
While a number of the articles already discussed above addressing Professor Zahra's contributions to the corporate entrepreneurship literature are also relevant to the corporate performance literature, he has also, in collaboration with J.A. Pearce, published, "Boards of Directors and Corporate Finance Performance: A Review and Integrative Model," in (1989) in the Journal of Management. Another of his important papers on corporate performance is "Contextual Influences on the Corporate Entrepreneurship-Performance Relationship: A Longitudinal Analysis," together with Jeff G. Covin, and published in (1995) in the Journal of Business Venturing.

\section{Conclusions}

Shaker A. Zahra has pioneered research into area fields and applications where no other scholar had been before. The result has been a greatly enriched view of the breadth and applicability of entrepreneurship as well as an impact and analytical insight that have significantly enhanced our understanding of entrepreneurship. Thanks to his path-breaking research and scholarship, future generations will have the advantage of being able to stand on the shoulders of Professor Zahra's pioneering scholarship in entrepreneurship.

Open Access This article is distributed under the terms of the Creative Commons Attribution License which permits any use, distribution, and reproduction in any medium, provided the original author(s) and the source are credited.

\section{References}

Cohen, W., \& Levinthal, D. (1989). Innovation and learning: The two faces of R\&D. The Economic Journal, 99, 569-596.

Cohen, W., \& Levinthal, D. (1990). Absorptive capacity: A new perspective on learning and innovation. Administrative Science Quarterly, 35(1), 128-152.

Zahra, S. (1991). Predictors and financial outcomes of corporate entrepreneurship: An exploratory study. Journal of Business Venturing, 6(4), 259-285.

Zahra, S. (1996). Governance, ownership, and corporate entrepreneurship: The moderating impact of industry technological opportunities. Academy of Management Journal, 39(6), 1713-1735.

Zahra, S. (2003). International expansion of US manufacturing family business: The effect of ownership and involvement. Journal of Business Venturing, 18(4), 495-511. 
Zahra, S. (2005). Entrepreneurial risk taking in family firms. Family Business Review, 18(1), 23-40.

Zahra, S. (2015). Corporate entrepreneurship as knowledge creation and conversion: The role of entrepreneurial hubs. Small Business Economics Journal, this issue.

Zahra, S., \& Covin, J. G. (1995). Contextual influences on the corporate entrepreneurship-performance relationship: A longitudinal analysis. Journal of Business Venturing, 10(1), 43-58.

Zahra, S., Gedajlovic, E., Neubaum, D., \& Shulman, J. (2009). A typology of social entrepreneurs: Motives, search processes and ethical challenges. Journal of Business Venturing, 24(5), 519-532.

Zahra, S., \& George, G. (2002). Absorptive capacity: A review, reconceptualization and extension. Academy of Management Review, 27(2), 185-203.
Zahra, S., Hayton, J., \& Salvato, C. (2004). Entrepreneurship in family vs. non-family firms: A resource-based analysis of the effect of organizational culture. Entrepreneurship Theory and Practice, 28(4), 363-381.

Zahra, S., \& Pearce, J. A. (1989). Boards of directors and corporate financial performance: A review and integrative model. Journal of Management, 15(2), 291-334.

Zahra, S., Rawhouser, H., Bhawe, N., Neubaum, D., \& Hayton, J. (2008). Globalization of social entrepreneurship. Strategic Entrepreneurship Journal, 2, 117-131.

Zahra, S., Sapienza, H., \& Davidsson, P. (2006). Entrepreneurship and dynamic capabilities: A review, model and research agenda. Journal of Management Studies, 43(4), 917-955. 